\title{
頸部椎間板障害に対する手術法の選択
}

\author{
岩崎 喜信·井須 豊彦・阿部弘
}

\section{Operative Methods for Cervical Disc Disease}

\author{
Yoshinobu IWASAKI, Toyohiko ISU and Hiroshi ABE \\ Department of Neurosurgery, Hokkaido University, Sapporo
}

\begin{abstract}
Seventy-seven patients with the cervical disc disease were surgically treated using operative microscope and air drill since 1976. These cases were analyzed with regard to operative methods and the criteria for selection of the operative method. The methods were selected by means of the preoperative neurological and radiological findings. The operative methods included: anterior discectomy with or without fusion, vertebrectomy with fusion, and laminectomy in which en bloc wide laminectomy was utilized. When selection of the operative methods was made according to the pathophysiological findings of the lesion, the operative results improved. However, some technical refinements still remained to be achieved. As a recent approach, lesions were removed as completely as possible by means of the anterior approach.
\end{abstract}

Key words: cervical spondylosis, soft disc, operative method, surgery

\section{I はじめに}

頸部椎間板障害は，近年，放射線学的検查法の進歩に上 る病態像の新たな解明に伴い，画一的な治療才法では対処 すべきものとは言えなくなってきている，手術方法に执い ても種々の改良や工夫がなされており $1,2,5,14,23)$ ，尔の治療 成績も向上してきている。しかしながら，手術方法の選択 基準に関しては，いまだ報告者により若干の違いがあ $ろ^{7,8,19,20)}$. 我ヶわ1959年以降, 現在までに頸椎椎間板障書 209例に対して外科的治療を行ってきたが，その経過中， 幾度か術式の改良ないしは変更を行った，本報告に招いて は，後方除圧法として en bloc wide laminectomy，および前 方到達法として顕微鏡下での北大式 Smith Robinson 法を 尊入した1976年以降の症例に関して主に術式選択の面上り 检討し，併世て現在我名が行っている術式の選択基淮を報 告する。

\section{II 対 象}

1976年以降に経験した頸部椎間板障害手術例は77例であ った。疾患別では soft disc 36例， spondylosis 41 例である。 なお， spondylosis の症例中11例は分節型の限局性の後縦 勒带骨化症 (以下 OPLL) 古合併していた，確定診断は頸 椎単純および断層撮影, CT scan, myelographyなど，種 々の検査にてなされたが, myelographyは必ず頚椎の前 屈・中閒・伸展位にて撮影寸るいわゆる dynamic myelography老行った．放射線学的検查所見上の障害椎間板数な らびにレベルをみる上, soft discでは1椎間のものが压倒 的に多く，36例中22例，61\%を占め，レベル別ではC4/5， C5/6に多く又ら机た。一万， spondylosis では逆に多椎間 の障害が多く、レベル別でもC4/5, C5/6の文仿らず，他 のレベルKも高頻度にみられた(Table 1)。

\section{III 神経症 状}

神経症状の分析に抋いて，従来は radiculopathy（root 
Table 1 Numbers of involved discs and the levels in cases of soft disc or spondylosis

\begin{tabular}{|c|c|c|c|c|c|c|c|c|c|}
\hline & \multicolumn{4}{|c|}{$\begin{array}{c}\text { No. of } \\
\text { involved discs }\end{array}$} & \multicolumn{5}{|c|}{ Levels } \\
\hline & 1 & 2 & 3 & 4 & C.3/4 & $\mathrm{C} 4 / 5$ & $\mathrm{C} 5 / 6$ & C6/7 & C7/Th1 \\
\hline $\begin{array}{l}\text { Soft dise } \\
\quad(36 \text { cases })\end{array}$ & 22 & 9 & 5 & 0 & 12 & 17 & 19 & 6 & 1 \\
\hline $\begin{array}{l}\text { Spondylosis } \\
\text { (41 cases) }\end{array}$ & 3 & 15 & 16 & 7 & 16 & 27 & 35 & 31 & 0 \\
\hline
\end{tabular}

Table 2 Neurological findings on admission

\begin{tabular}{cccccc}
\hline & & \multicolumn{2}{c}{ Segmental sign } & \multicolumn{2}{c}{ Long tract sign } \\
\cline { 4 - 5 } \cline { 4 - 5 } & & Motor & Sensory & Motor & Sensory \\
\hline $\begin{array}{c}\text { Soft disc } \\
(36 \text { cases })\end{array}$ & 28 & 21 & 30 & 24 \\
$\begin{array}{c}\text { Spondylosis } \\
(41 \text { cases })\end{array}$ & 36 & 24 & 36 & 23 \\
\hline
\end{tabular}

sign) と myelopathy (cord sign) とに分计て検討することが 多かったが，近年，上肢症状のなかに根障宫に上るのか存 䯣障害によるのか必ずしも区別が困難な症状のあるこにが 判明した1,2,10,17)。そこで，合回は神経症状を segmental sign とlong tract sign Łに分けて検討した。な放, soft disc O21例, spondylosisの22例では神経学的に明らかな root signが認められた。検討の結果はTable 2 のごとくて あり, soft disc 症例, spondylosis 唗例と屯に segmental sign ๖ long tract signの間で特に差はみられなかったし たがって神経学的所見のみから注 soft disc と spondylosis との鑑別は不叮能であるが，媈動障書と知覚障害の重篤度 は全体的に spondylosisの汪うが強い傾向がみられた。

\section{N 手術方法}

手術方法 0 内訳法，椎弓切除法(en bloc wide laminectomy）が18例，前方到详法が52例で茄るが，後者のうち12 例には discectomy without fusion(以下 without fusion と略

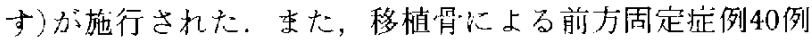
中 7 例は spondylosisて， osteophyte の限局性の OPLL 合併例であり，これらの症例に対して は椎体削除 (vertebrectomy)による osteophyte や OPLL の 除去の上，移植骨による固定が行わ扎た。さらに，前方な い儿後方除圧の双では症状改善が十分でるからた7症例に 対しては，兩者の併用が行われた。

疾患別の手術方法をみると， soft disc の36例では前方除 压のみが32例，前方除压上椎弓切除の併用が 4 例であり，
椎弓切除単独例はなかった。如效して, spondylosis O41例で惟弓讶除が18例，前方除正肪20例，両者の侻用 3 例之椎局切除例 6比較的多い。しふ・しながら，近年では

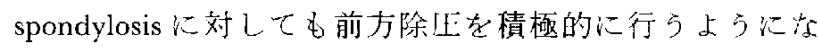
ってさている。ささら，前方除任においても osteophyte OPLLの完全な除去を行らの友ならず，術脽梌査で

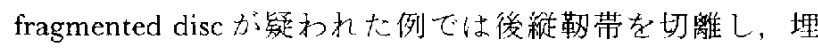
没している disc 当完全に摘话している。なお， without fu一 sionに招いては術後の後繸勒帯の“たわ子”の可能性を考

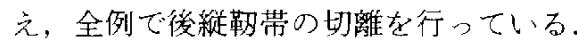

\section{$\mathrm{V}$ 手術成績}

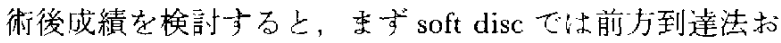
よび椎弓切除法を含め, 総計で segmental sign, long tract sign ともに90\%以上の改善率を得ている(Table 3).な招，

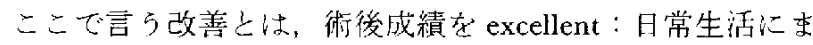
ったく支障がない, good：わずかな症状の残存はあるお゙ 日常生活は介助不要である，fair：日常生活になんらかの 介助要寸る, poor：全介助必要の4段階に分けたなかか ら good以上のbのを指与。前方到達法を術式別にみる そ, interbody fusion では89\%, without fusion ではその適

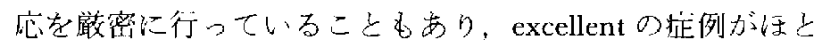
んどである。次に spondylosisでは，般に術前の症状が 重蒸で発症か心手術までの期間が長い傾向があるので，総 計で segmental sign 76\%, long tract sign 87\% と改善率は soft disc に比 Lて悪く，改善の程度も excellent $の$ 占㐬 が低くなっている，術式別では椎ら切除施行例の改善率が もっとも低く，特に segmental sign は56\%と約半数に改善 がみられたにすぎない，一方，前方到達法ではvertebrectomy $の$ 例女念め, segmental sign, long tract sign $と も に$ に 好な結果を得ている(Table 4)。广お，術後の觢柱配列の 異常については，椎弓切除例で4例に kyphosis がみ゙られ， 前方固定例では椎間固定不全 1 例，椎体が軽度ずれたま李 固定されたもの3 例を譛めた。しかしなからら、これらに上

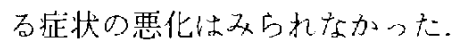

\section{U 術式選択基準}

手術成績を考虑しつつ，種々の変遷を経て，現在我々は 術式の選択基準としてFig. 1のごき力法をとっている. すな和り， soft discでは3椎間レベル以下の障噩の場合， $1 な い し 2$ 椎間の病変で subluxationのない症例には without fusion 行い(Fig. 2)，3椎間の病变息たは subluxationがある症例には interbody fusionを行っている。 この理由は, subluxationがある場合， without fusionでは 術後椎体間が亜脱臼のま去定される可能性があるためて 
Table 3 Postoperative results (soft disc)

\begin{tabular}{|c|c|c|c|c|c|c|c|c|c|c|c|c|}
\hline & \multicolumn{2}{|c|}{$\begin{array}{l}\text { No. of } \\
\text { cases }\end{array}$} & \multicolumn{2}{|c|}{ Excellent } & \multicolumn{2}{|c|}{ Good } & \multicolumn{2}{|c|}{ Fair } & \multicolumn{2}{|c|}{ Poor } & \multicolumn{2}{|c|}{$\begin{array}{c}\text { Rate of } \\
\text { improvement }\end{array}$} \\
\hline & $\mathrm{S}$ & $\mathrm{L}$ & $\mathrm{S}$ & $\mathrm{L}$ & $\mathrm{S}$ & $\mathrm{L}$ & $S$ & $\mathrm{~L}$ & $\mathrm{~S}$ & $\mathrm{~L}$ & $S$ & $\mathrm{~L}$ \\
\hline $\begin{array}{l}\text { Anterior disccctomy }(32 \text { cases }) \\
\text { Interbody fusion (20 cases) } \\
\text { Without fusion (12 cases) }\end{array}$ & $\begin{array}{l}19 \\
12\end{array}$ & $\begin{array}{r}19 \\
7\end{array}$ & $\begin{array}{l}12 \\
11\end{array}$ & $\begin{array}{r}13 \\
6\end{array}$ & $\begin{array}{l}5 \\
1\end{array}$ & $\begin{array}{l}4 \\
1\end{array}$ & $\begin{array}{l}2 \\
0\end{array}$ & $\begin{array}{l}2 \\
0\end{array}$ & $\begin{array}{l}0 \\
0\end{array}$ & $\begin{array}{l}0 \\
0\end{array}$ & $\begin{array}{r}89 \% \\
100 \%\end{array}$ & $\begin{array}{r}89 \% \\
100 \%\end{array}$ \\
\hline Laminectomy - anterior fusion ( 4 cases: & 4 & 4 & 2 & 2 & 1 & 2 & 1 & 0 & 0 & 0 & $75 \%$ & $100 \%$ \\
\hline Total ( 36 cases) & 35 & 30 & 25 & 21 & 7 & 7 & 3 & 2 & 0 & 0 & $91 \%$ & $93 \%$ \\
\hline
\end{tabular}

$\mathrm{S}$ indicates segmental sign; L, long tract sign.

Table 4 Postoperative results (spondylosis)

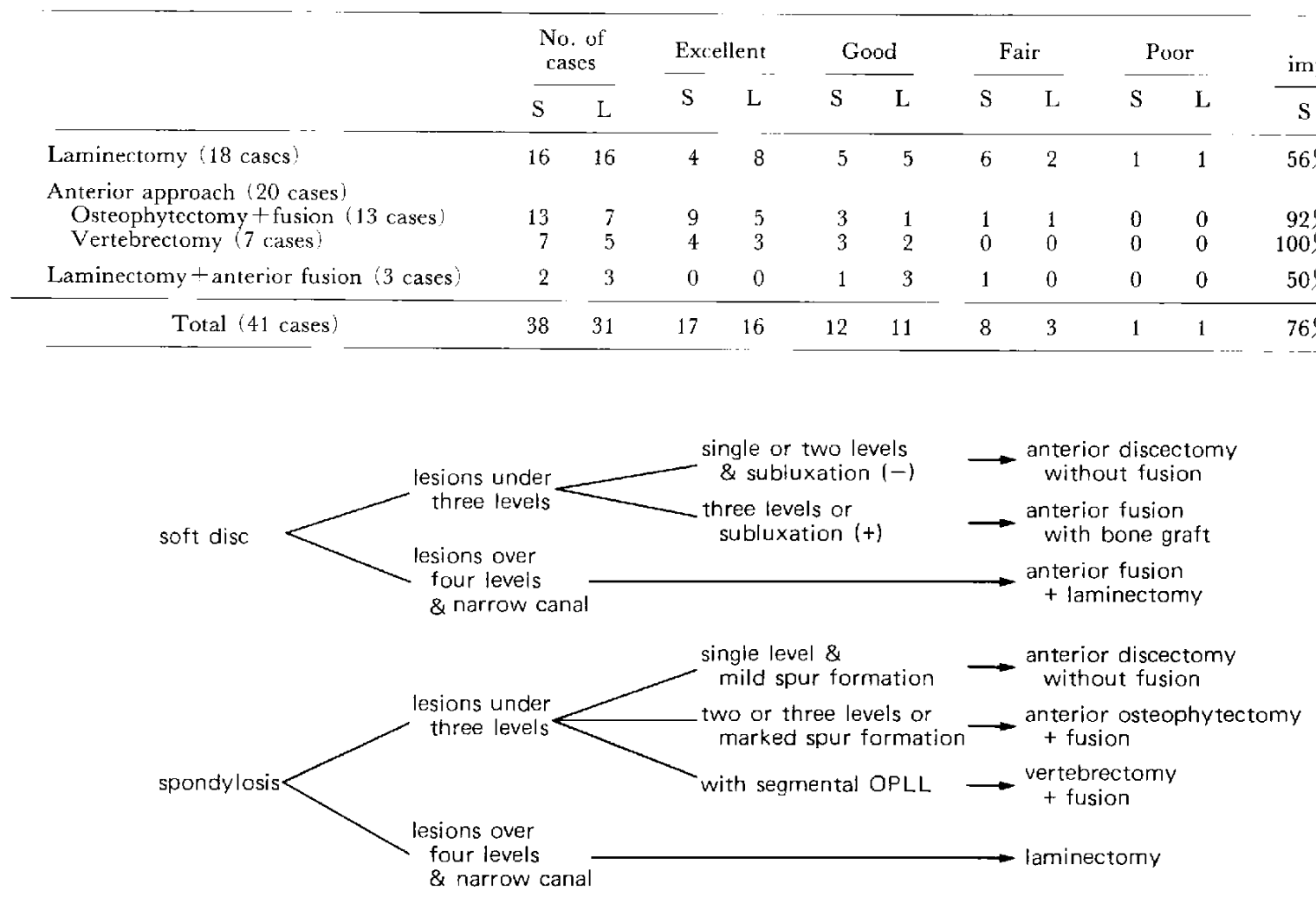

Fig. 1 Criteria for the selection of operative method. OPLL indicates ossification of posterior longitudinal ligament.

两る，以上の基準は，障害が 3 椎間以下であ机ば脊椎管狭 窄の有無にかかわらず選択適応となる。一方，障害が 4 椎 間以上で有椎管狭窄を伴ら例には前方固定に椎弓切除を併 用するが，実際には soft discで 3 椎間以に:病栄を有する 症例は注とえどない，これに対し，spondylosisでは3椎 間レベル以下の障害の場合，1椎間の病変で osteophyteが 軽度のものには osteophyte 除去の与, without fusion t行 う.しかし、, osteophyteが著明なるのや $2 \cdot 3$ 椎間の障害
のものには osteophyteの除去と移植骨による骨固定を行う （Fig. 3)．己らに，分節型の OPLLを合併するものには椎 体削除に上り骨化宩を摘除した上で骨固定を行5(Fig. 4).一方，4椎間以上の障害で著明な春䯣の圧迫を呈する 場合，または脊椎管前方からの压迫は軽度で合併する脊椎 管狭窄のほうが主たる場合には椎弓切除が第一選択となる が，症例によっては前方固定術が併用されることもある (Fig. 5). 


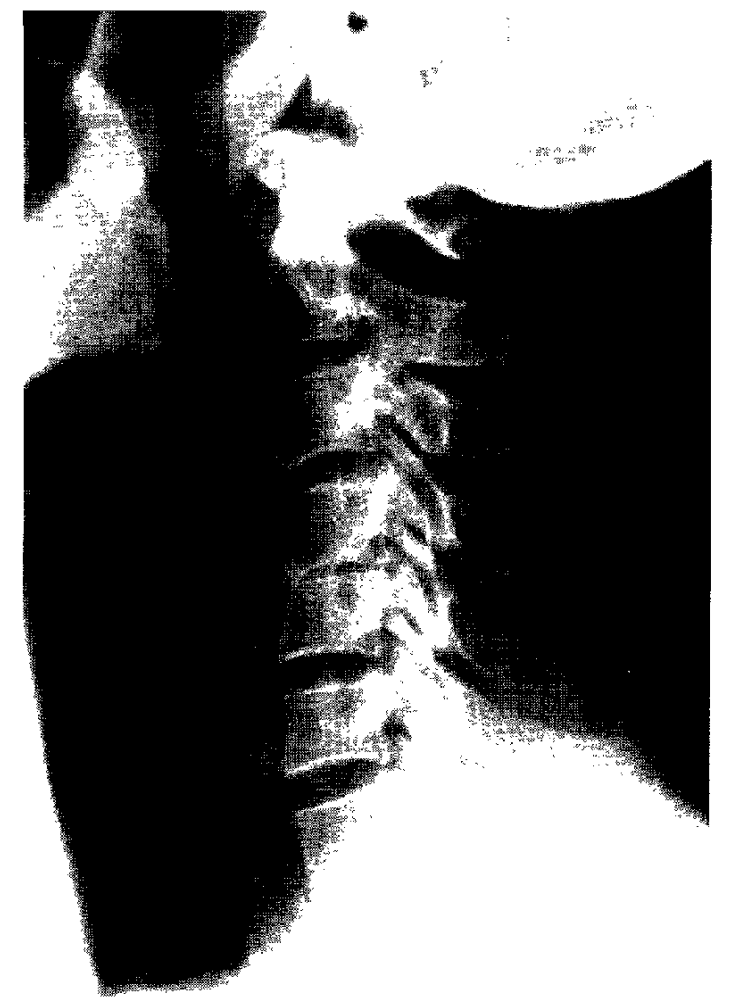

Fig. 2 Cervical X-ray showing anterior discectomy without fusion at the level of $\mathrm{C} 4 / 5$.
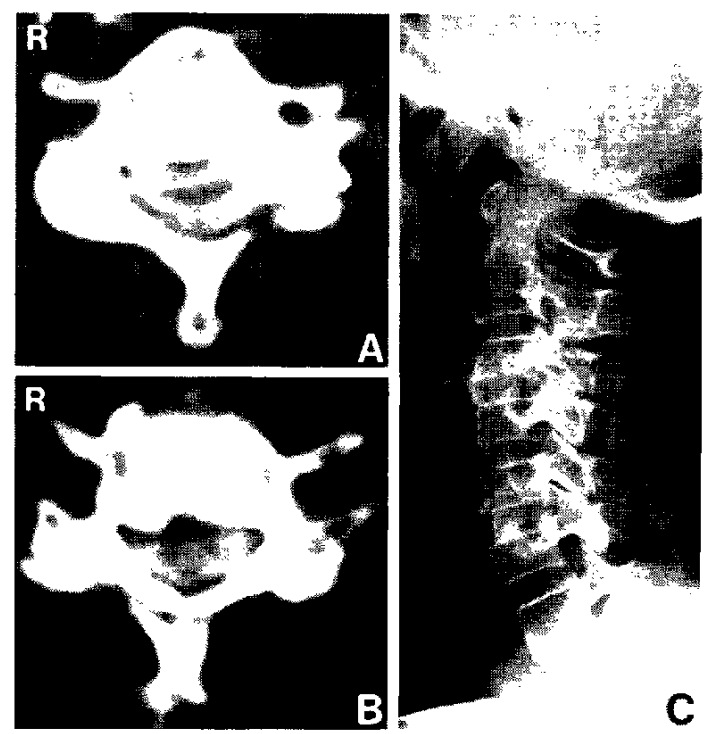

Fig. 3 A, B: Preoperative computed tomography myelograms showing osteophytes and disc protrusion at $\mathrm{C} 4(\mathrm{~A})$ and C6 (B) levels. C: Postoperative cervical X-ray showing anterior fusion at $\mathrm{C} 3 / 4$ and $\mathrm{C} 5 / 6$ levels.

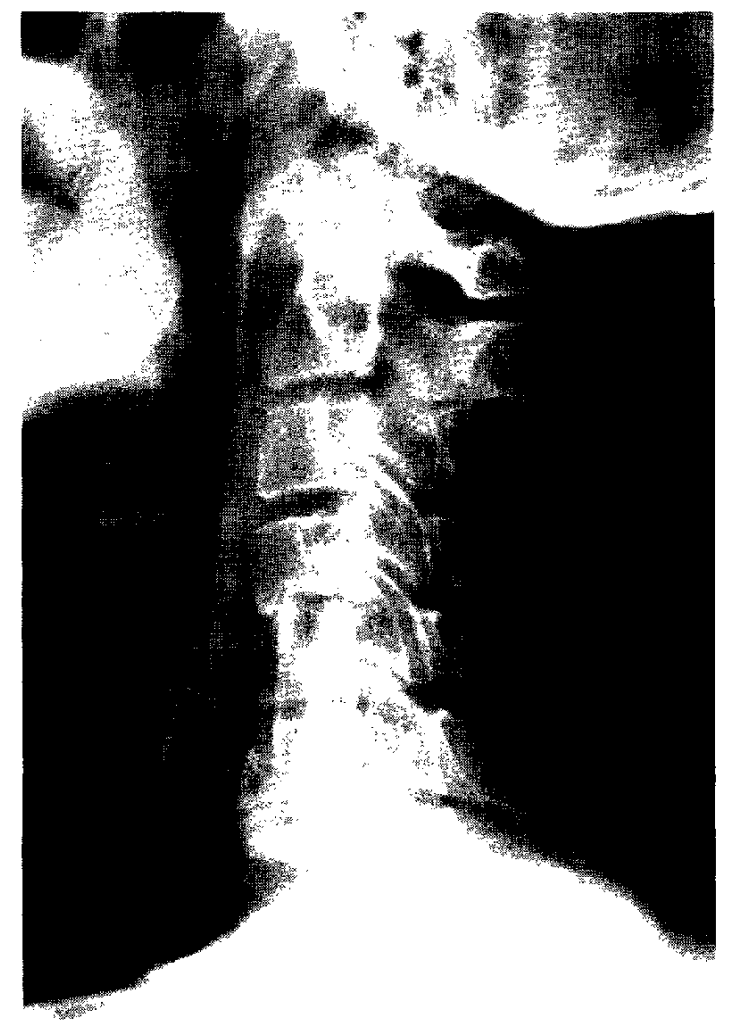

Fig. 4 Cervical X-ray showing vertebrectomy and fusion.

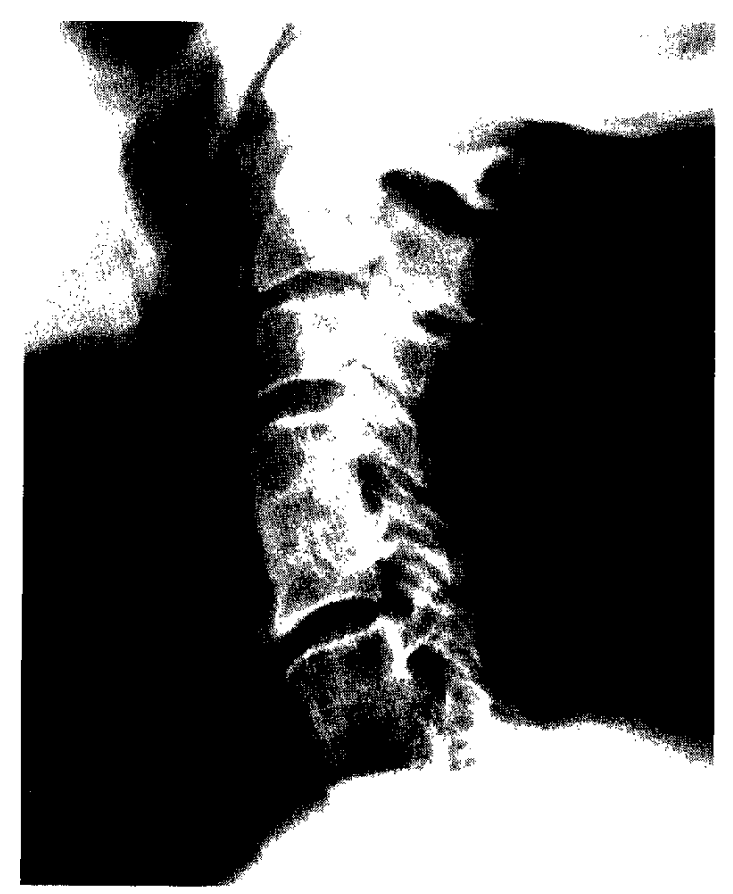

Fig. 5 Anterior fusion combined with laminectomy. 


\section{VI 考 察}

頸部椎間板障害に対する治療は，頸部カラーや頸部絫引 を初めとする保存的治寮と前方ないしは後方到達法による 手術的治療があるが，治療方法の選択，特江手術的治療の 選択は，頸部椎間板障害の病態像の新たな解明や術式の改 良に伴い，時代ととも沉变遷してきた16,18,24,25,28)．その歴 史的変遷の詳細は別にして，大委かにみると，1950年前後 より laminectomyに関する報告が数多く出されたが，1950 年代後半に Cloward ${ }^{31}$ およびSmith ら 27)，そして Robinson ら ${ }^{22)}$ により前方到達法の術式が報告され，これ以後, 前方除圧法と後方除厌法とが常に比較娭討される上らにな った，後方除圧に関しても，Kahn ${ }^{12)}$ の説を基礎として dentate ligament の切離を良しとするもの，あるいは逆に 害とするものなど，一時期論争があった4,15,201が，1960年 以降はこの切離は一般には行われなくなった，1960年代に 入ると Hink ら6沉より developmental narrow spinal canal の概念が提唱され，これにより後方除圧の意義が再度見直 された。さらに，この時期 Scoville ${ }^{26}$ らに上り神経根除圧 を目的として laminectomy $に$ facetectomyが加えられるよ うになり，只の手術成績は向上した。本邦に拁いても都留 $ら^{29)}$ ，長島ら ${ }^{16 i}$ こら積極的にこの方法が取り入れられ た。しかしながら，1960年代後半上り手術顕徽鏡の導入拉 上び手術器具の改良に上り, 前方からの病巣の徹底的な除 去が安全に行われる上らになり，このため，以後，前方到 達法が徐々に後方到達法を陵駕する上らになっだ,11,15)。 さらに1970年前後上り，前方到垟法のつとして移植骨を 用いない，いわゆる without fusion 法も症例を選択した上 で採用されるようになった21,23!。しかし，一方で後方到達 法に関しても改良がなされ，1970年代には従来のレクセル 鉗子やチリソンパンチなどによる椎弓切除代代って air drill 老用いた en bloc wide laminectomyが行われるよらにな った 4,7,13). 以上の上らな手術選択の変遷汇伴い，我々の 教室に拈いてもまた，手術法の改良拉よび手術選択の变更 が行われてきたことは当然と言える。

当科比括る術式の変遷を示すと，その初期には soft disc, spondylosis と米隹椎弓切除術(症例によっては facetectomyを併用)が行わ机ていたが，1963年より soft disc 汇詨 してはCloward 法が採用され，また1968年からは一部で はあるが spondylosis にも同法が適用されるよらになった。 巳らに，1975年には手術顕微鏡の導入に伴い，前方到澾法 はCloward 法から北大式 Smith-Robinson 変法が主とな り, 症例に上っては without fusion または椎体亜全摘術も 行われるよらになった。一方，後方除压子現在はすべて en bloc wide laminectomy がなされている(Fig. 6).

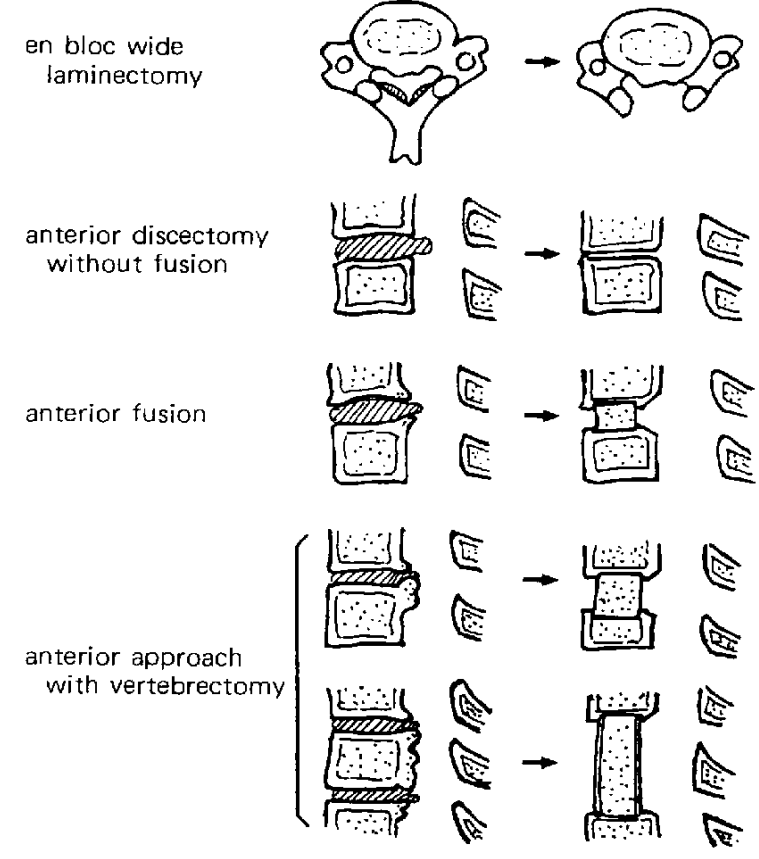

Fig. 6 Our operative methods for cervical disc diseases.

次に手術適応に関しても，以前に報告した criteria ${ }^{17,29)}$ と幾分变ってきている，すなわら，以前はその条件として (1) myelopathy が重篤で, さらに manometric Queckenstedt test(以下 MQT) で blockのあるもの，(2) myelopathy は軽 度であるが，頸部カラーを主とする保存的療法が無効なも の，(3)頸部カラーである程度症状の改善をみるも，年龄が 若く，今後長期にわたる社会的活動により頸椎への負担が 予想される症例が挙げられた。しかしながら，その後日本 人の平均寿命の大幅な延長, 手術操作の安全性の向上, ま た手術月的が症状改善のみならず症状増悪の予防にまで拡 大されつつあることより，適応条件を多少変えさるをえな くなってきている，さらに，近年の CT scanや水溶性造 影剂の開発により, 脊䯣ならびに神経根障害の病態像が dynamic study CT myelography 基に詳細に知りうる

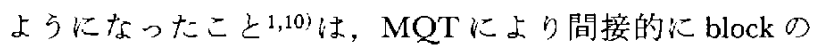
程度を知る意味を薄れさせてきている，我々は現在，沾療 基準を以下のごとく考えている，すなわち，(1)急性増覀例 を別にして，radiculopathy たな myolopathyを有する症 例に対し，まず $1 \sim 2$ カ月間は頸部カラーや安静などによ る保存的治療を行う。この際, 急性期症例て椎間板突出に よる春髄ならびに神経根の圧迫を呈している症例以外は原 則として頸部章引を行わない，そして，この保存的治療を 行っている期間に種々の放射線学的検索を行5. (2)神経症 状を有し，放射線学的検索で奉噵ないしは神経根の圧迫が 
認められ，さらに保存的治潦が無効または改善を認めても 尔和症状が軽度で当残存与る場合，手術適応々なる。(3)怔 例の年齢が70才以下てあれば，応すべてが千術の対家上 なる。以上のよ5に，我々の教室に拀いては手術適心の籁 用は以前と比較して应大してきている。

一般に術式選执に来汁る最近の傾向として，できるか心 $り$ 前方到達法による病巣の南接的摘出を行らよらになって きており，その成績も问上してきている。しかしながらい

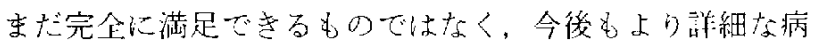
態像の解明と上正手術法の改良がなされる必要がある。

\section{VIIIおわりに}

1. 頝部椎間板障害77例につき，主に手術術式の面より 検討した。

2. 椎間板障告は病单が符椎管の前万以ある上，でき

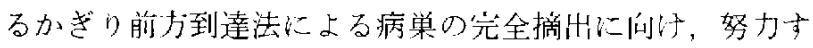
ベさである。

3. 前方到達法に蛙 without fusion, interboby fusion, vertebrectomy, laminectomy $と の$ 併用など, 種々の術式が あるが，術前の神経学的所見扣上び放射線学的所見より責 佂病栄レベルを決定し, 頸椎の動的変化による神程亚迫の 程度, 後維勒帯の穿破の有無, 春髄髄内変化の程度などを 確実に把握し，女口上も適切な術式を選択すべさである。

\section{女 献}

1）阿部 弘, 少崎喜信: 项椎症一私の治療方針一, 夕リ二力 9: $53-59,1982$

2）阿部弘，岩崎喜信：变形性異椎症. Clin Neurosci 2: 56-59, 1984

3) Cloward RB: The anterior approach for removal of ruptured cervical discs. $J$ Neurosurg 15: 602-617, 1958

4) Fager CA: Results of adequate posterior decompression in the relief of spondylotic cervical myelopathy. J Neurosurg 38: 684-692, 1973

5) Hankinson HL, Wilson CB: Use of the operating microscope in anterior cervical discectomy without fusion. $J$ Neurosurg 43 : 452456,1975

6) Hink VC, Gordy PD, Sforino HE: Developmental stenosis of the cervical canal. Brain 89: 27-36, 1966

7) 平林 洌：頸椎症の外科的治療。神経内科 1:205-214,1974

8) Hunt WE: Cervical spondylosis: Natural history and rare indication for surgical decompression. Clin Neurosurg 27: 466-480, 1980

9) 井上駿一, 黒岩璋光, 宮坂 右, 鈶木 宖: Cervical spondylotic myelopathyの前方法汇よる手術成續の吟味. 監整外 10: 1018-1034, 1975

10）岩绮喜信, 阿部弘, 井須豊彦, 都留美都婎, 宫圾和男, 三森研自：Small cavity 立合併した cervical spondylosis $\emptyset$ 検討.
CT 讲究 6:319-323, 1984

11) 角家 暁, 中村 勉，江守 厉：Cervical spondylosis 如刘 寸る手術用顕微鏡下前方手術汇ついて七。手術 33：1275-1278， 1979

12) Kahn EA: The role of dentate ligaments in spinal cord compression of the syndrome of lateral sclerosis. J Neurosurg 4: 191-199, 1947

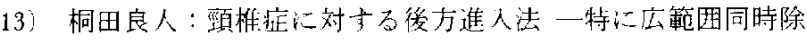
圧式椎与切除術を巾心に一。整外 MOOK 6: 216-230，1979

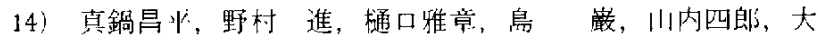

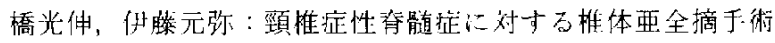
に刘与る娭討。整形外科 27：1023-1031，1976

15) Mayfield FH: Cervical spondylosis: A comparison of the anterior and posterior approaches. Clin Neurosurg 13: 181-188, 1966

16）長島親男，坂口 新：Ccrvical spondylosis上椎間孔開放術。 腷神外科 $7: 7-23,1979$

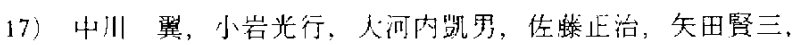
都留美都堆 : Cervical disc disease $の$ 外科的治療法 0 遠隔域績 脳と神 25: 1681-1689, 1973

18) Nurick $S$ : The pathogenesis of the spinal cord disorder associated with cervical spondylosis. Brain 95: 87-100, 1972

19) 小野村䑤信：手術の商応と術式の選抧。整外 MOOK 6: 180-194, 1979

20) Piepgrass DG: Posterior decompression for myelopathy due to cervical spondylosis: Laminectomy alone versus laminectomy with dentate ligament section. Clin Neurosurg 24: 508-515, 1977

21) Robertson JT: Anterior removal of cervical disc without fusion. Clin Neurosurg 20: 259-261, 1973

22) Robinson RA, Walker AE, Perlic DC: The results of anterior interbody fusion of the cervical spine. J Bone Joint Surg [Amer] 44 1569-1587, 1962

23) Rosenorn J, Hansen EB, Rosenorn MA: Anterior cervical discectomy with and without fusion. J Neurosurg 59: 252-255, 1983

24）作藤正治，都留美都犨：Cervical spondylosis 々頸椎看椎管 前後径につててその1)。脳袖外科 4: 359-364，1976

25）佐藤正治, 都留美都雄: Cervical spondylosis 上頸椎脊椎管

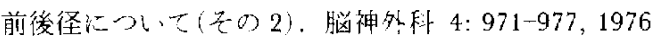

26) Scoville WB: Cervical spondylosis treated by bilateral facetec: tomy and laminectomy. J Neurosurg 18: 423-428, 1961

27) Smith GW, Robinson RA: The treatment of certain cervical spine disorders by anterior removal of the intervertebral disc and interbody fusion. J Bone Joint Surg [Amer, 40: 607-624, 1958

28) Stoltmen HF, Blackwood $W$ : The role of the ligamentum flava in the pathogenesis of myelopathy in cervical spondylosis. Brain 87: $45-54,1964$

29）都留美都雄，阿部 弘：Cervical spondylosis, disc $の$ 手術。 脳神外科 3: 15-20,1975

[別刷請求先：干060 札煶市北区北15条西7丁目, 北海道大学脳 神释外科, 岇崎喜信] 